\title{
COUP Transcription Factor 2
}

National Cancer Institute

\section{Source}

National Cancer Institute. COUP Transcription Factor 2. NCI Thesaurus. Code C75869.

COUP transcription factor 2 (414 aa, $\sim 46 \mathrm{kDa}$ ) is encoded by the human NR2F2 gene.

This protein is involved in the mediation of transcription. 